\title{
ASPEK DAKWAH DALAM NOVEL SURIATI BERDASARKAN PENDEKATAN DAKWAH TEORI PENGKAEDAHAN MELAYU
}

\section{(The Proselytization Aspect in the Novel Suriati Based on the Proselytization Approach of the Malay Methodology Theory)}

\author{
*Nadia Ishak \\ nad_ishak22@yahoo.com
}

\section{Kamariah Kamarudin}

kkamaria@upm.edu.my

Jabatan Bahasa Melayu, Fakulti Bahasa Moden dan Komunikasi, Universiti Putra Malaysia.

Published on: 3 June 2019

To cite: Nadia Ishak and Kamariah Kamarudin. (2019). Aspek dakwah dalam novel Suriati berdasarkan pendekatan dahwah teori Pengkaedah Melayu. Malay Literature 32(1), 116-144.

\begin{abstract}
Abstrak
Penulisan novel berbentuk keagamaan merupakan salah satu medium dakwah yang berkesan yang digunakan penulis untuk menyebarkan ajaran Islam dan meningkatkan ketakwaan terhadap Allah SWT. Kajian ini akan menyingkap aspek dakwah dalam novel yang memaparkan pergolakan dan konflik kekeluargaan yang mengangkat tema keagamaan sebagai latar karya. Tumpuan difokuskan terhadap kekuatan dan keberkesanan dakwah yang mencorakkan kehidupan manusia ke arah kebaikan dan meninggalkan kebatilan dalam novel Suriati karya Azizi Haji Abdullah. Pendekatan Dakwah yang terkandung dalam teori Pengkaedahan Melayu dimanfaatkan sebagai kerangka analisis. Hasil kajian memperlihatkan bahawa dakwah berupaya menimbulkan daya tarikan terhadap agama Islam dan menjadi alat untuk pengembangan agama Islam.
\end{abstract}


Kata kunci: dakwah, agama, teori, ketakwaan, masyarakat

\section{Abstract}

The writing of religious novels is one of the most effective mediums of proselytization that can be used by writers to spread the teachings of Islam and increase people's faith in Allah SWT. This study uncovers the aspects of proselytization in novels that employ religious themes as backgrounds for works dealing with family conflict. The focus is on Azizi Haji Abdullah'novel, Suriati, which shows the strength and effectiveness of proselytization in leading people towards a life of goodness and avoidance of falsehood. The proselytization approach of the Malay Methodology (Pengkaedahan Melayu) was employed as a framework for analysis. The findings of this study reveal that proselytizing elements are able to create an interest in Islam and may be used as a means to spread the word of Islam.

Keywords: proselytization, religion, theory, faith, society

\section{PENDAHULUAN}

Dakwah dari sudut istilah mempunyai pelbagai pengertian. Menurut tokoh dakwah al-Aluri (1979, p. 16), dakwah ialah usaha memalingkan pandangan dan pemikiran manusia kepada akidah yang memberikan manfaat kepada mereka. Dakwah juga merupakan seruan untuk menyelamatkan manusia daripada melakukan kesesatan atau maksiat yang hampir menjerumuskan mereka kepadanya. Ali Mahfuz (1975, p. 18) pula menjelaskan maksud dakwah sebagai usaha yang dilakukan untuk menggalakkan manusia melakukan kebaikan, memberi petunjuk, menyuruh melakukan yang makruf dan mencegah yang mungkar bagi mencapai kejayaan di dunia dan akhirat. Menurut Ab. Aziz (1997, p. 3) pada asasnya dakwah ialah usaha yang dilakukan oleh seseorang atau kumpulan dengan pendekatan tertentu untuk membawa manusia menuju ke jalan yang diredai Allah SWT.

Berdasarkan beberapa pengertian tersebut, dapat disimpulkan bahawa dakwah merupakan mekanisme atau wadah untuk memperkembang dan menyebarluaskan syariat Islam. Selain itu, dakwah juga dapat diertikan sebagai usaha mengajak manusia mengabdikan diri kepada jalan Allah SWT. Berdakwah merupakan tuntutan fardu kifayah untuk mengembalikan umat Islam mengamalkan ajaran Islam yang sebenar dalam kehidupan. Oleh itu, dakwah perlu dilakukan menerusi saluran yang bersesuaian bagi 
memastikannya dapat berkembang dan disebar luas secara hikmah dan teratur. Perihal mengenai dakwah ini dapat dilihat dalam Surah al-Nahl ayat 125 yang bermaksud:

Serulah ke jalan Tuhanmu (wahai Muhammad) dengan hikmat kebijaksanaan dan nasihat pengajaran yang baik dan berbahaslah dengan mereka (yang engkau serukan itu) dengan cara yang lebih baik. Sesungguhnya Tuhanmu Dialah jua yang lebih mengetahui akan orang yang sesat dari jalannya, dan Dialah jua yang lebih mengetahui akan orang-orang yang mendapat hidayah petunjuk.

(Mushaf Tajwid Berserta Terjemahan ke dalam Bahasa Malaysia, 2006, p. 281)

Ayat di atas menjelaskan bahawa seruan dan ajakan manusia ke jalan Allah SWT perlu mengikut landasan dan juga pendekatan yang bersesuaian agar tidak menjadi fitnah kepada agama Islam itu sendiri dan seterusnya membinasakan perpaduan umat Islam seantero dunia. Ayat ini turut menuntut para $d a$ ' $i$ untuk menggunakan pendekatan dakwah yang mengandungi wasilah yang bersesuaian bagi menarik umat Islam untuk berjihad ke jalan Allah SWT.

Tugas dan tanggungjawab manusia adalah untuk berbakti kepada Allah SWT. Umat Islam dituntut untuk berjihad ke jalan Allah bagi mendapat keberkatan di dunia dan akhirat. Setiap makhluk di muka bumi ini tidak terkecuali untuk mengabdikan diri kepada Allah SWT dan perlu menyahut seruan bagi mengembangkan syiar Islam. Seruan dakwah ini turut dijelaskan di dalam Surah al-Adz-Dzaariyaat ayat 56 yang bermaksud:

"Dan Aku tidak menciptakan jin dan manusia melainkan supaya mereka menyembah-Ku".

(Mushaf Tajwid Berserta Terjemahan Ke Dalam Bahasa Malaysia 2006, p. 523)

Pengertian ayat ini menjelaskan bahawa jin dan manusia diciptakan untuk beribadah kepada Allah SWT dan perlu dilakukan dengan penuh ketaatan dan tunduk kepada Yang Maha Esa. Ayat ini juga turut mengajak manusia untuk beribadah ke jalan Allah SWT dan senantiasa mencari keredaan-Nya. Secara zahirnya, ayat ini menjelaskan bahawa manusia dan jin diciptakan untuk beribadah kepada Allah SWT dan bukannya untuk 
melakukan kemungkaran dan kemaksiatan. Oleh itu, kesemua makhluk yang diciptakan oleh Allah SWT tidak terkecuali untuk tunduk dan mengabdikan diri kepada-Nya.

Usaha dakwah perlu seiring dengan perancangan dan pengurusan yang baik bagi menghasilkan suatu produk yang memuaskan. Perancangan dakwah yang berkesan perlu melihat metode yang bersesuaian bagi menentukan hasil yang baik dan menepati sasaran dakwah. Berdakwah secara melulu tanpa perancangan memberikan impak yang negatif terhadap golongan sasaran dakwah. Setiap pendekatan mempunyai kekuatannya yang tersendiri dalam menyampaikan mesej dakwah. Namun begitu, secara umumnya dakwah wujud dalam bentuk lisan, tulisan dan contoh teladan dan akhlak yang ditunjukkan oleh seseorang (Shofian, 2011, pp. 45-55).

Antara pendekatan dakwah yang paling berkesan termasuklah menerusi kaedah penulisan. Penulisan berbentuk buku merupakan metode yang berkesan dalam menyebarkan dakwah ke jalan Allah SWT. Pendekatan ini telah digunakan oleh al-Ghazali dalam usaha menyampaikan dakwah kepada golongan pemerintah pada zamannya. Al-Ghazali menyebarkan dakwah menerusi mata pena atau penulisan yang dapat dibahagikan kepada dua, iaitu penulisan buku dan penulisan surat yang dihantar kepada pemerintah (Salasiah Hanin, 2010, p. 59). Pendekatan yang digunakan al-Ghazali ini berkesan dalam menyebarkan dakwah ke setiap pelosok dunia. Oleh itu, dalam usaha menyampaikan dakwah secara berhikmah seseorang itu perlu mempelajari pendekatan terbaik bagi mempengaruhi sasarannya.

Sehubungan dengan konteks yang dibincangkan ini, penghasilan karya yang berunsur dakwah amat dituntut dalam penyebaran agama Islam. Karya yang bermutu dan berkesan secara tidak langsung dapat menyebarluaskan ajaran Islam. Kewujudan sastera Islam pada awal 1970an di Malaysia menyelitkan unsur dakwah yang menjadi pencetus kepada penggiat karya sastera Melayu untuk menghasilkan lebih banyak penulisan berbentuk keagamaan. Sastera Islam hadir ketika kesusasteraan Melayu amat mendambakan hasil sastera yang bercorak keagamaan yang seterusnya dapat membentuk perilaku manusia ke jalan yang diredai Allah SWT, berlandaskan akidah Islam.

Sehubungan dengan ini, kehidupan masyarakat yang tidak lekang dengan pergolakan dan lebih mementingkan aspek duniawi berbanding akhirat lantas mengetepikan ajaran Islam menjadi ilham pengarang untuk berkarya. Karya yang berunsur dakwah ini diyakini dapat mengembalikan akidah umat Islam yang dilihat semakin terpesong daripada ajaran Islam. 
Apa-apa yang terhasil daripada karya yang berbentuk dakwah ini merupakan pengucapan akidah umat Islam bagi menarik umat Islam yang dilihat pada hari ini kian tersasar daripada landasannya.

Oleh itu, kajian ini memanfaatkan teori dan pendekatan dakwah yang diterapkan untuk memberikan manfaat kepada para pengkaji karya keagamaan dalam mengkaji dan membicarakan kesusasteraan Islam secara ampuh dan jelas. Teori yang diaplikasikan bagi memperlihatkan aspek dakwah ialah pendekatan dakwah yang terkandung dalam Teori Pengkaedahan Melayu.

\section{TEORI PENGKAEDAHAN MELAYU}

Teori Pengkaedahan Melayu telah dikemukakan oleh Hashim Awang pada tahun 1989. Teori ini lahir daripada pengamatan Hashim mengenai kehidupan, kepercayaan dan kebudayaan masyarakat Melayu. Gagasan teori ini bersandarkan akar kehidupan dan kebudayaan masyarakat Melayu, berasaskan kitab Tajul Muluk ${ }^{1}$ yang mengandungi pelbagai ilmu dan juga panduan hidup bangsa Melayu.

Pengkaedahan Melayu berteraskan falsafah hubungan akrab orang Melayu dengan alam. Oleh itu, teori ini memusatkan penghasilan karya sastera yang berpaksikan jati diri orang Melayu secara zahiriah dan batiniah. Menurut Hashim, sebagai suatu bangsa besar yang mampu mencipta karya sastera agung, kita sudah pasti berupaya membina teori dan kritikan sastera sendiri yang lebih sempurna dan mantap. Beliau menambah, sebagai suatu bangsa besar yang mampu mencipta karya sastera agung, kita sudah pasti berupaya membina teori dan kritikan sastera sendiri yang lebih mantap dan sempurna. Sejajar dengan ini, maka beliau mewujudkan suatu teori sastera sendiri, iaitu Teori Pengkaedahan Melayu. Teori ini dibentuk berasaskan cara dan sikap hidup (weltanschauung), pandangan dunia, perspektif alam semesta (kosmologi) dan agama (Islam) orang Melayu yang memiliki ciptaan karya sastera yang tinggi dan unik (Hashim, 1999, pp. 5-6). Secara dasarnya, teori Pengkaedahan Melayu merupakan salah satu teori yang menggunakan pendekatan Islam dalam pengisian gagasannya. Oleh itu, rumusan yang dapat disimpulkan ialah Teori Pengkaedahan Melayu yang bertitik tolak daripada konsep agama dan budaya ialah saduran kehidupan dan juga keagamaan Melayu Islam. Secara ringkas, Teori Pengkaedahan Melayu dapat diperlihatkan seperti dalam Rajah 1.

Pengkaedahan Melayu ini (Hashim Awang, 2002, p. 12) terbahagi kepada dua, iaitu pengkaedahan alamiah dan pengkaedahan keagamaan. Pengkaedahan alamiah terdiri daripada pendekatan gunaan, moral dan juga 


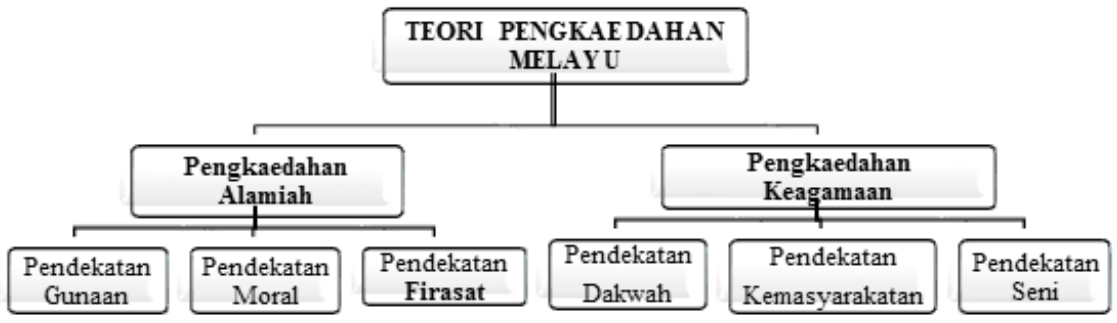

Rajah 1 Teori Pengkaedahan Melayu.

(Sumber: Teori Pengkaedahan Melayu oleh Hashim Awang, 1994).

firasat. Pengkaedahan keagamaan pula terdiri daripada pendekatan dakwah, kemasyarakatan dan seni. Pengkaedahan keagamaan ialah pendekatan berdasarkan keimanan yang bersendikan akidah agama Islam. Pengkaedahan ini wujud berdasarkan agama Islam sebagai agama anutan masyarakat Melayu. Rujukan paling utama ialah al-Quran dan al-Hadis. Pengkaedahan ini bersendikan nilai estetika dan moral yang bersandarkan pegangan yang benar dan kudus, iaitu kepercayaan kepada kewujudan Allah SWT dan keyakinan kepada sifat kebesaran, kekuasaan, kekayaan, dan kesempurnaanNya. Pembentukan Pengkaedahan keagamaan adalah untuk menonjolkan sifat keagungan Allah SWT dan meningkatkan ketakwaan manusia.

Oleh itu, pemilihan pendekatan dakwah menerusi pengkaedahan keagamaan yang terdapat dalam teori Pengkaedahan Melayu signifikan dan bersesuaian untuk digunakan dalam kajian ini, kerana menawarkan ruang lingkup mengenai pemahaman dakwah yang dapat mempengaruhi dapatan kajian ini nanti. Pendekatan Dakwah memperihalkan kebesaran dan keagungan Allah SWT. Pendekatan ini juga menimbulkan daya tarikan yang mendalam terhadap kesucian agama Islam. Sejajar dengan ini, pendekatan dakwah menjurus penelitian karya sastera sebagai alat pengembangan Islam dan keagungan Allah SWT. Karya sastera umpama dakwah yang mengajak manusia melakukan kebaikan dan meninggalkan kemungkaran. Pemikiran dalam novel yang akan dikaji ialah novel yang berunsurkan Islam dengan pemaparan jalan cerita yang menunjukkan kesyumulan Islam dari segenap aspek kehidupan manusia. 


\section{METODOLOGI KAJIAN}

Analisis ini menggunakan pendekatan dakwah, iaitu salah satu pendekatan menerusi pengkaedahan keagamaan dalam teori Pengkaedahan Melayu. Menerusi pengkaedahan keagamaan, sastera dianggap sebagai alat mengagungkan kebesaran Allah SWT dan mempertingkatkan keunggulan agama Islam. Menurut Hashim (2003, p. 20), sastera ditanggapi sebagai mengandungi persoalan yang memaparkan pengisahan tentang sifat-sifat kemuliaan dan ketinggian Allah SWT sehingga dapat dijadikan semacam "kitab" yang daripadanya pembaca dapat mengenali dan menghayati dengan lebih dekat dan khusyuk tentang diri dan sifat Allah SWT yang demikian bertujuan menambahkan dan mempertingkatkan rasa kecintaan dan kehormatan manusia yang lebih besar dan suci terhadap-Nya. Oleh itu, sastera yang berunsurkan dakwah berfungsi memperkembang agama Islam melalui nilai-nilai murni dan keistimewaan yang diyakini dapat menimbulkan daya tarikan untuk mengenali agama Islam dengan lebih dekat. Pengarang menerusi karyanya menggunakan sastera yang berunsurkan dakwah sebagai usaha untuk menyeru dan membawa manusia ke jalan yang diredai Allah SWT.

Sehubungan dengan ini, pendekatan dakwah yang digunakan untuk kajian ini bersesuaian dengan karya Azizi Haji Abdullah, iaitu novel Suriati (1993) yang bertemakan keagamaan. Novel ini pernah memenangi Hadiah Sastera (Hadiah Pertama Sayembara Novel Islam (1993) anjuran Bahagian Hal Ehwal Islam: Jabatan Perdana Menteri. Novel Suriati memaparkan pergolakan dan juga konflik kekeluargaan yang sarat dengan persoalan agama yang berkaitan dengan nilai ketakwaan, keimanan dan kemuliaan.

Kajian ini mengkaji sejauh mana kekuatan dan keberkesanan aspek dakwah yang melatari novel Azizi Haji Abdullah yang berunsurkan keagamaan dengan menggunakan teori Pengkaedahan Melayu menerusi pendekatan dakwah. Melalui kajian ini, pengkaji menganalisis beberapa aspek dakwah dengan merujuk metodologi dakwah ${ }^{2}$ yang diperkenalkan oleh al-Faruqi. Ringkasnya, carta alir perkaitan metodologi dakwah ini dengan pendekatan dakwah menerusi teori Pengkaedahan Melayu dapat diperlihatkan seperti dalam Rajah 2.

Selain itu, Pendekatan yang diperkenalkan oleh al-Faruqi ini mengemukakan beberapa metodologi dakwah yang perlu dijadikan panduan oleh umat Islam bagi mengembangkan dan mempertingkatkan keunggulan Islam. Ismail al-Faruqi merupakan tokoh penting terhadap pemikiran yang berkaitan dengan dakwah Islam. Beliau menggunakan metode al-Quran dan 


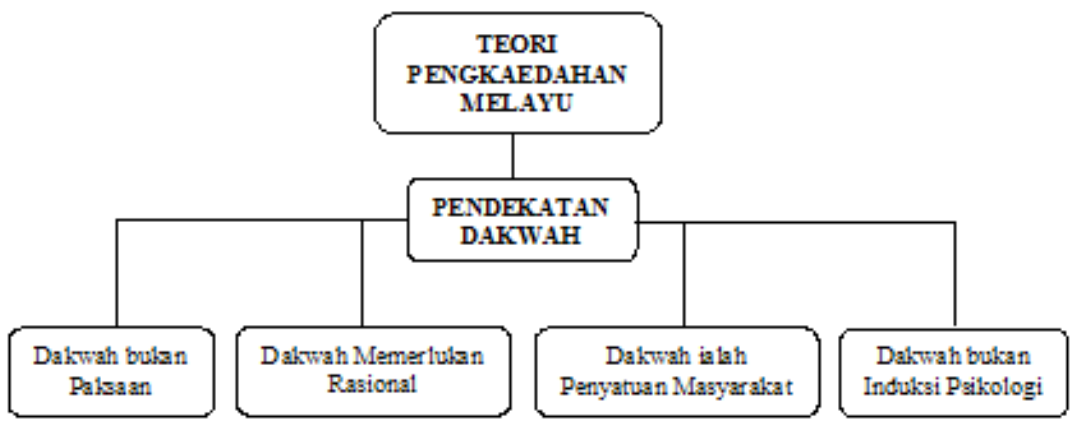

Rajah 2 Carta alir teori Pengkaedahan Melayu dan metodologi dakwah.

hujah akal dalam menyampaikan dakwah manakala isi kandungan dakwah pula merupakan huraian konsep tauhid yang digagaskannya (Ahmad Sabri Osman, 2013, p. 97). Cakupan dakwah al-Faruqi mengandungi pengertian kebebasan, rasional dan universal. Pendekatan yang digunakan oleh al-Faruqi ini memberi panduan kepada para pendakwah untuk menggunakan kaedah secara hikmah dan tertib tanpa menggunakan kekerasan. Menurut al-Faruqi, pelbagai pendekatan boleh digunakan asalkan selari dengan panduan yang ditetapkan oleh syarak. Kajian ini menggunakan empat cakupan metode dakwah yang diperkenalkan oleh al-Faruqi. Pendekatan dakwah akan dinilai dari aspek; dakwah bukan paksaan; dakwah bersifat rasional; dakwah bukan induksi psikologi dan dakwah adalah gerakan penyatuan yang unggul.

\section{SINOPSIS}

Novel Suriati mengisahkan dua watak utama, iaitu Suriati dan Anuar yang ketandusan kasih sayang daripada kedua-dua ibu bapa mereka. Dua watak utama ini merupakan pelajar sekolah Menengah yang mendapat tugasan untuk mencantumkan penulisan mereka menjadi sebuah novel. Rancangan untuk mencantumkan penulisan kedua-dua pelajar ini cetusan idea guru Bahasa Malaysia mereka yang berasa terdapatnya kesamaan jalan cerita dan sesuai untuk digabungkan menjadi sebuah novel yang menarik. Episod perjalanan novel ini bermula apabila pendedahan demi pendedahan dikemukakan, iaitu rahsia lampau yang selama ini disimpan kemas oleh kedua-dua ibu bapa Suriati dan Anuar kembali dibongkar. Pendedahan yang meruntun jiwa yang 
terpaksa diterima oleh Suriati dan Anuar ialah kenyataan bahawa keduaduanya adik beradik kandung yang mempunyai pertalian darah.

\section{ANALISIS DAN PERBINCANGAN}

Dakwah membawa pengertian kegiatan menyeru dan meyakinkan orang lain supaya menerima sesuatu kepercayaan (Kamus Dewan Edisi Keempat, 2015, p. 305). Dakwah dari sudut bahasa diberikan pelbagai takrif oleh tokoh pendakwah antaranya termasuklah Sayyid Nawfal (1997, p. 17) menjelaskan perkataan dakwah itu berasal daripada kata kerja dasarnya $d a^{\prime} a$ dan kata nama terbitannya $a l-d u^{\prime} a^{\prime}$. Dakwah hadir dalam bentuk tulisan, lisan dan contoh teladan serta akhlak yang ditunjukkan oleh seseorang. Tulisan dalam bentuk bahan bacaan, manakala lisan melalui penyampaian yang kebiasaannya disampaikan oleh $d a^{\prime} i^{3}$ kepada mad' $u{ }^{4}$

Dalam novel Suriati aspek keagamaan yang berunsurkan dakwah yang diterapkan dalam watak-watak. Novel ini mengungkapkan dakwah sebagai mesej utama yang mendasari jalan cerita. Dakwah dianggap sebagai suatu mekanisme untuk menyebarluaskan syariat Islam dan meliputi segenap kehidupan manusia bersesuaian dengan ajaran Islam yang bersifat syumul.

Persoalan yang mengaitkan aspek dakwah dalam karya digarap dengan cukup sempurna oleh pengarang, iaitu sebagai satu usaha yang dilakukan untuk menggalakkan manusia ke arah kebaikan dan mencegah kemungkaran bagi mencapai kejayaan dunia dan akhirat.

\section{Dakwah Bukan Paksaan}

Dalam Islam berdakwah dengan cara paksaan bukanlah pendekatan dakwah yang dituntut, malah dilarang keras sama sekali. Dakwah perlu dilakukan dengan cara yang berhemah dan lembut bagi menjamin keberkesanannya. Pernyataan ini diperkuat dengan firman Allah SWT dalam Surah al-Baqarah ayat 256 yang bermaksud:

Tidak ada paksaan dalam (menganut) agama (Islam), sesungguhnya telah jelas antara jalan yang benar dengan jalan yang sesat. Barang siapa ingkar kepada thaghut dan beriman kepada Allah, maka sesungguhnya dia telah berpegang (teguh) kepada buhul tali yang 
sangat kuat yang tidak akan putus. Allah Maha mendengar lagi Maha mengetahui.

(Mushaf Tajwid Berserta Terjemahan Ke Dalam Bahasa Malaysia 2006, p. 42)

Ayat berikut menjelaskan bahawa dakwah membimbing dan mengajak manusia untuk mengenali Islam dengan lebih dekat dan menyelamatkan manusia daripada kesesatan dan kemungkaran. Ayat ini juga menjelaskan maksud bahawa tiada berlakunya sebarang paksaan dalam menerima Islam bahkan Allah SWT mencegah perbuatan sedemikian dilakukan. Oleh itu, dakwah juga perlu dilakukan dengan cara yang tertib tanpa menggunakan sebarang paksaan. Islam bukan agama yang menggunakan kekerasan untuk berdakwah dalam mengembangkan syiar Islam, malah Islam ialah agama yang mempunyai jalinan toleransi dalam menyebarluaskan agama tersebut.

Selain itu, Islam mengalakkan masyarakat yang bebas untuk menyuarakan pandangan serta berbahas mengenai agama antara satu sama lain. Menurut (al-Faruqi, 1998, p. 6) gambaran mengenai situasi ini disamakan dengan sebuah seminar akademik yang besar dan sesiapa sahaja yang mempunyai pengetahuan yang mendalam mengenai sesuatu perkara bebas untuk menyatakan pandangan dan buah fikiran mereka, manakala individu yang lain juga bebas untuk mendengar dan menerimanya. Agama Islam tidak pernah meletakkan sebarang sempadan kepada umat Islam untuk menentukan secara rasional mengenai perkara yang dianggap munasabah dan mereka mempunyai hak untuk menentukan antara hak dan yang batil. Pendekatan yang diambil oleh al-Faruqi ini dianggap pendekatan yang rasional dalam berdakwah. Masyarakat bebas menyuarakan pandangan masing-masing mengenai agama Islam asalkan tidak bertentangan dengan al-Quran dan al-Sunnah. Tiada paksaan dalam dakwah Islam untuk menerima agama yang syumul ini.

Sejajar dengan itu, menerusi novel Suriati terserlah aspek dakwah yang dikemukakan pengarangnya menerusi watak Masudah Steinmann. Hal ini dapat ditelusuri menerusi dakwah bukan paksaan. Dakwah hadir dalam diri seseorang dengan kerelaan individu terbabit. Dakwah di antara da ' $i$ dan mad' $u$ perlu ada jalinan antara kedua-duanya agar mesej dakwah dapat disampaikan dengan jayanya. Watak Masudah Steinmann, iaitu wanita Inggeris yang telah memeluk Islam setelah berkahwin dengan Marzuki mempamerkan konsep dakwah yang berlaku secara sukarela tanpa sebarang paksaan. Minat yang mendalam dan mempunyai perasaan 
ingin tahu yang ditunjukkan oleh Masudah terhadap Islam digarap dengan cukup sempurna pada awal plot novel ini. Masudah yang pada mulanya menanam kebencian dan mempunyai persepsi yang negatif terhadap agama Islam sama sekali telah meruntuhkan tembok keegoannya terhadap agama ini, iaitu dengan secara tidak sengaja telah membaca kitab al-Quran di perpustakaan. Kecenderungannya untuk mendalami Islam atas kehendak dirinya sendiri dan bukannya paksaan daripada mana-mana pihak. Dakwah yang diperlihatkan di sini berbentuk tulisan, iaitu Masudah tertarik dengan agama Islam melalui bahan bacaan tafsir al-Quran yang dibelinya di kedai buku. Paparan ini dapat dilihat menerusi petikan di bawah:

Aku membeli sebuah buku tafsir al-Quran yang ditulis oleh seorang pengarang Muslim ... Aku sendiri tidak tahu, sebaik saja aku memandang kulit buku tafsir yang aku beli, aku sudah jadi tertarik hendak membaca hingga habis. Di dalam kamar, malam itu juga aku mula membaca. Aduh, sebaik-baik saja aku memulakan dengan surah al-Fatihah yang hanya tujuh ayat itu, aku menjadi tersangat kagum. Aku rasa seluruh kehidupan manusia dapat mencantumkan dua dunia, iaitu alam ini dengan alam akhirat.

(Azizi Haji Abdullah, 2009, p. 138)

Petikan teks tersebut menyatakan bahawa dakwah tidak hanya wujud dalam bentuk lisan. Dakwah juga berupaya dilakukan dalam bentuk penulisan. Watak Masudah Steinmann dilihat begitu tertarik dengan keunikan agama Islam yang dianggapnya amat menyenangkan. Walaupun dilahirkan dan dibesarkan dalam keluarga konservatif yang menganut agama Kristian Protestan, Masudah masih mencari-cari pengertian agama yang sebenar. Sehinggalah, beliau dipertemukan dengan jawapan kepada persoalan mengenai agama, iaitu Islam. Impak daripada pembacaan kitab tafsir al-Quran yang dibelinya merupakan satu anjakan paragdigma yang berlaku dalam dirinya. Masudah berasa bagaikan menerima suatu kekuatan yang merungkai segala kekusutan yang dicari-carinya selama ini. Dakwah hadir dalam konteks ini secara sukarela dan bukan paksaan, iaitu Masudah memperoleh seruan dakwah melalui kitab tafsir al-Quran yang dibacanya. Oleh itu, dapat disimpulkan bahawa Islam menuntut umat Islam untuk berdakwah ke jalan Allah SWT, namun pendekatan berdakwah itu sendiri perlu selari dengan garis panduan yang telah ditetapkan oleh syarak. Oleh itu, hal ini sejajar dengan teori Pengkaedahan Melayu menerusi pendekatan dakwah dari 
aspek "Dakwah bukan Paksaan", iaitu dakwah perlu dilaksanakan dengan penuh ketertiban tanpa menggunakan sebarang kekerasan serta paksaan. Agama Islam bersandarkan kepada kebebasan menerima dakwah tanpa menggunakan paksaan yang bertentangan dengan objektif dakwah.

Selain itu, Islam bukan agama yang menggunakan kekerasan untuk berdakwah dalam mengembangkan syiar Islam, malah Islam sebuah agama yang mempunyai jalinan toleransi dalam menyebarluaskan agama tersebut. Penemuan Masudah menerusi pembacaannya tentang keunggulan agama Islam, iaitu menerusi nilai keistimewaan dan kemurnian agama tersebut.

Dakwah juga perlu dilakukan dengan cara yang lembut tanpa menggunakan sebarang paksaan. Dakwah perlu dilakukan dengan penuh kesantunan dan berhemah bagi menarik minat umat Islam dan yang bukan Islam untuk mengabdikan diri ke jalan Allah SWT. Golongan ini perlu diberikan perhatian sewajarnya dan perlu dipandang dengan kasih sayang, toleransi, serta bijaksana agar tanggungjawab dakwah kepada mereka berjaya. Umat Islam harus mencontohi cara junjungan nabi Muhammad SAW menyebarkan agama Islam kepada masyarakat Arab Jahiliah pada ketika itu. Nabi Muhammad SAW menggunakan pendekatan yang berhemah dan menolak dakwah berbentuk kekerasan dan atas dasar inilah agama Islam yang akhirnya diterima oleh masyarakat Jahiliah sebagai anutan mereka dan agama yang benar.

Selain itu, dakwah melalui penulisan ini sekali lagi disentuh oleh penulis yang membabitkan watak utamanya, iaitu Masudah dalam menerima dakwah melalui pembacaannya. Masudah dilihat terpegun dengan keindahan nilai-nilai Islam yang diperoleh melalui pembacaan buku-buku berbentuk keagamaan dan dakwah:

Aku teringat sebuah buku yang pernah aku baca di perpustakaan Perth dulu tentang kebagusan budaya yang dibentuk oleh Islam dan akhlak Muhammad yang menjadi pemimpin itu. Buku itu cukup adil memberi gambaran tentang Islam. Patutlah Muhammad dapat membentuk bangsa Quraisy menjadi bangsa yang bersopan padahal kaum Quraisy satu bangsa yang kekar dengan sifat-sifat biadab. Dan selesai azan, aku merenungi kecubung begitu lama. Aku nampak seperti sebutir bintang yang bertenggek di atasnya, berkelipan dan bersinar. Aku seperti dapat membaca satu bentuk ayat yang indah seni tulisnya dan seni itu sangat cepat menyerap ke dalam jiwaku. Aku teringat sebuah buku sejarah tentang Sayidina Umar yang menggeletar seluruh tubuhnya oleh sepotong ayat yang dibaca oleh 
adiknya. Sungguh, aku bukan saja terpengaruh dengan bahan bacaan yang pernah aku baca, tetapi lebih jauh dari itu aku kagum tentang Islam yang dapat membentuk manusia sebagai taabud khaliknya.

(Azizi Haji Abdullah, 2009, pp166-167)

Keghairahan Masudah untuk mengenali Islam semakin hari semakin kuat dan pertemuannya dengan sepasang keluarga Islam menambahkan lagi kecenderungannya untuk terus mendalami agama tersebut. Masudah mempelajari tentang cara hidup, kehidupan dan kepercayaan orang Islam melalui pemerhatian dan pembacaannya dan ternyata mendekatkannya lagi dengan agama Islam. Baginya, Islam sebuah agama yang indah dari sudut zahiriah dan lahiriah. Masudah memeluk Islam setelah mengahwini Marzuki, dan reda atas ketentuan Ilahi yang mentakdirkannya hidup sah sebagai isteri walaupun hanya sebagai isteri kedua. Plot jalan cerita memperlihatkan pendekatan dakwah yang berlaku terhadap diri Masudah mencapai matlamatnya.

Kronologi dapat dilihat daripada awal plot cerita, iaitu pada mulanya tersemat perasaan benci dalam diri Masudah terhadap agama Islam dan setelah beliau membaca kitab tafsir al-Quran, persepsi Masudah terhadap Islam dilihat mula terhakis. Masudah dilihat mula mendekatkan diri dan mendalami agama Islam dengan membaca buku berbentuk keagamaan (Islam). Perkenalannya dengan sebuah keluarga Islam merapatkan lagi jiwa beliau terhadap Islam. Masudah akhirnya memeluk Islam setelah mengahwini Marzuki memperkemaskan lagi keberkesanan dakwah yang dilalui oleh Masudah.

Oleh itu, hal ini sejajar dengan teori Pengkaedahan Melayu menerusi Pendekatan Dakwah dari aspek "Dakwah bukan Paksaan", iaitu Islam bukan merupakan agama yang menggunakan kekerasan untuk berdakwah dalam mengembangkan syiar Islam, malah Islam agama yang mengambil pendekatan secara tertib dan berhemah. Dakwah secara paksaan merupakan perbuatan yang tidak dianjurkan dalam Islam. Dalam hubungan ini, setiap mukmin berkewajipan untuk menyebarkan agama Islam (berdakwah) mengikut kemampuan masing-masing. Dakwah dalam Islam terlaksana, apabila umat Islam mempraktikkan dan mempamerkan keindahan Islam dalam kehidupan yang menjadi contoh kepada manusia sejagat, secara harmoni dan sejahtera.

Keindahan Islam dalam kehidupan itulah yang dipraktikkan oleh Masudah setelah memeluk agama Islam. Watak Masudah diperlihatkan 
sering menghabiskan masa mempelajari agama, membuat kerja-kerja sukarela, memberi ceramah kepada saudara baru di Rumah Orang Tua, melakukan amal ibadat di masjid dan membantu anak-anak yatim. Masudah memperlihatkan kecekalan menghadapi dugaan yang menimpa dirinya dan menganggap itu adalah ketentuan daripada-Nya:

Tapi mujurlah ajaran agama yang aku pelajari begitu kuat meresap dalam jiwaku. Islam bagiku adalah 'jalan hidup'. Semuanya ini aku anggap takdir dan ketentuan Allah. Aku telah bersumpah seluruh hidupku demi Islam dan aku rela mati kerananya. Malamnya aku sembahyang sunat hampir tiga puluh rakaat dan berkali-kali pula aku sembahyang istikharah. Aku pohon petunjuk dan kesabaran daripada Allah.

(Azizi Haji Abdullah, 2009, pp. 57-58)

Plot jalan cerita memperlihatkan kecekalan Masudah menghadapi ujian daripada Yang Maha Esa. Masudah memenuhi masanya dengan mendekatkan diri dengan Allah SWT. Masudah reda dengan apa yang menimpa dirinya dan menganggap dugaan yang diturunkan kepadanya adalah sebagai takdir yang perlu dilaluinya. Perkahwinan Masudah dan Marzuki diketahui oleh isteri pertamanya iaitu Halijah dan ditentang keras oleh isteri pertama suaminya itu. Namun begitu, Masudah akur dengan segala caci makian yang dilemparkan kepadanya dan menerima hukum Allah SWT dengan kerelaan hatinya. Oleh itu, hal ini sejajar dengan teori Pengkaedahan Melayu menerusi Pendekatan Dakwah dari aspek "Dakwah bukan Paksaan" iaitu Islam bukan merupakan agama yang menggunakan kekerasan untuk berdakwah malah Islam adalah sebuah agama yang mengambil pendekatan secara berhemah.

\section{Dakwah Memerlukan Rasional}

Dakwah dalam konteks Islam bersifat rasional. Dakwah yang rasional d ialah dakwah yang kritis, iaitu dakwah yang berlandaskan sesuatu yang benar berasaskan ilmu pengetahuan. Oleh itu, dakwah tidak bersandarkan atas nama agama semata-mata, malah pengertian dakwah dalam Islam lebih luas pengertiannya. Dakwah merupakan penilaian kritis berdasarkan unjuran secara teori dan praktikal. Sehubungan dengan ini, dakwah memerlukan rasional bermaksud penerangan yang disampaikan hendaklah berdasarkan fitrah dan kebenaran yang rasional. Rasional di sini bermaksud bersedia 
menerima kritikan. Pandangan Islam bukanlah berasaskan "akta agama" tetapi berdasarkan keyakinan yang teguh, berasaskan ilmu, dan keyakinan yang berada dalam bidang kuasa manusia untuk mengetahuinya. Pernyataan tersebut menjelaskan bahawa dakwah tidak mempertaruhkan fahaman yang melulu. Dakwah berlandaskan fakta dan logika dan bersesuaian dengan pemikiran manusia yang bertamadun. Oleh itu, dakwah dalam Islam tidak sama sekali menjadikan agama sebagai tiket untuk menghalalkan perkara yang salah. Dakwah yang rasional berteraskan pemikiran yang kritis berdasarkan al-Quran yang bersifat sejagat dan diterima oleh semua manusia.

Oleh itu, berdakwah bukanlah suatu tugas yang mudah. Hal ini demikian kerana kerana pendakwah perlu melakukannya dengan pendekatan yang bersifat rasional bagi menarik minat mad'u untuk mentaati dan menyerahkan jiwa dan raga mereka kepada Allah SWT. Muhammad al-Ghazali (1981, p. 17) yang menjelaskan bahawa dakwah itu bukanlah suatu seruan tanpa tujuan tetapi dakwah merupakan satu program (barnami) lengkap yang semua peringkatnya mengandungi semua ilmu pengetahuan yang diperlukan oleh manusia bagi menjelaskan tujuan dan matlamat hidup serta menyingkap petunjuk Allah SWT yang menjadi pedoman kepada mereka. Penyataan ini memperjelaskan bahawa dakwah berupaya menyeru manusia kepada kebaikan dan menjauhkan diri daripada melakukan kebatilan yang boleh menghilangkan keberkatan di dunia dan di akhirat. Dakwah berupaya mengembalikan umat Islam mengamalkan ajaran Islam sebenar dalam kehidupan.

Untuk tujuan itu, pendakwah perlu mempunyai ilmu yang mencukupi bagi meyakinkan sasaran dakwahnya. Kekuatan ilmu yang dimiliki oleh pendakwah inilah yang membantunya untuk meletakkan sesuatu pada tempatnya dan tepat pada masanya. Pendakwah perlu menggunakan segala pengetahuan yang ada bagi menyebarkan aktiviti pendakwahan. Pernyataan ini diperkuat lagi dengan firman Allah SWT dalam Surah al- Baqarah ayat ke-231 yang bermaksud:

Dan (kenangkanlah) apa yang diturunkan kepada kamu iaitu kitab (al-Quran) dan ilmu hikmah untuk memberi pengajaran kepada kamu dengannya.

(Mushaf Tajwid Berserta Terjemahan ke dalam Bahasa Malaysia 2006, p. 37) 
Ayat tersebut menyatakan bahawa pendakwah dalam konteks ini perlu bersifat rasional dan menggunakan kebijaksanaan berlandaskan ilmu pengetahuan dan tidak lari daripada sumber al-Quran dan al-hadis ketika membahaskan sesuatu persoalan tentang agama. Sifat ini amat penting bagi sasaran dakwah membuat penilaian dan pertimbangan wajar terhadap dakwah yang diterimanya. Pernyataan ini sekali lagi diperkukuh dengan firman Allah SWT dalam Surah Saad ayat ke-26 yang bermaksud:

\begin{abstract}
Hai Daud, sesungguhnya Kami menjadikan kamu khalifah (penguasa) di muka bumi, maka berilah keputusan (perkara) di antara manusia dengan adil dan janganlah kamu mengikut hawa nafsu, kerana ia akan menyesatkan kamu dari jalan Allah. Sesungguhnya orang-orang yang sesat akan mendapat azab yang berat, kerana mereka melupakan hari perhitungan.
\end{abstract}

(Mushaf Tajwid Berserta Terjemahan Ke Dalam Bahasa Malaysia 2006, p. 454)

Oleh itu, keperibadian pendakwah amat penting dalam menyebarkan rasional sesuatu pembahasan dakwah. Keperibadian pendakwah yang memiliki sifat tersebut dapat menarik minat sasaran dakwahnya dalam menerima mesej yang disampaikan oleh pendakwah. Oleh itu, dakwah yang mencapai matlamatnya adalah apabila pendakwah berupaya membahaskan persoalan agama dengan rasional dan bernas, dan mesej yang disampaikan itu sampai kepada sasarannya.

Novel Suriati memperlihatkan aspek dakwah bersifat rasional dari awal hingga penghujungnya. Watak utama yang memulakan plot awal ini ialah Anuar, iaitu anak Marzuki yang mempunyai perasaan kurang bersetuju dengan tindak-tanduk ayahnya yang kurang menumpukan perhatian kepadanya sebagai seorang anak tunggal dalam keluarganya. Bapa Anuar lebih mementingkan kerjayanya sebagai seorang guru dan penulis sambilan yang digambarkan hidup dalam dunianya yang tersendiri dengan menghabiskan masa untuk berkarya. Watak Anuar yang membenci bapanya jelas dilihat dalam jalan cerita novel ini. Beliau kecewa dengan sikap bapanya yang tidak mengambil tahu tentang kebajikannya sebagai seorang anak. Namun begitu, atas pegangan agama yang utuh, Anuar sering bermuhasabah diri agar tidak membenci bapanya. Sementelahan, Islam turut menyebut bahawa berdosa besar apabila seorang anak memusuhi kedua-dua ibu bapanya. Perihal ini dinyatakan seperti petikan berikut: 
Tapi segala-galanya tidak dapat memadamkan kemarahanku padanya. Aku tahu ini berdosa besar walaupun ini satu perasaan. Menurut hukum agama dan ajaran ustaz, berdosa kepada ibu bapa bukan sahaja terbatas pada tindak laku, malah jika ada perasaan buruk pun sudah cukup menjadi penghalang masuk syurga. Aduh, betapalah aku. Ya Allah, lemparkanlah perasaan ini.

(Azizi Haji Abdullah, 2009, p. 26)

Petikan di atas menyerlahkan sifat Anuar sebagai seorang anak yang berfikiran secara rasional dan tidak mengambil keputusan secara terburuburu. Oleh hal yang sedemikian, atas dasar hukum-hakam agama yang diterima daripada ustaznya, Anuar memadamkan perasaan benci terhadap bapa kandungnya. Beliau tahu perbuatan membenci kedua ibu bapa ialah perbuatan yang dilaknat oleh Allah SWT. Mentaati dan berbakti kepada kedua ibu bapa adalah wajib dalam Islam. Menderhaka dan enggan mentaati kepada kedua-dua ibu bapa berdosa besar dan digolongkan dalam empat dosa besar. Keadaan ini jelas berdasarkan kata-kata nabi Muhammad SAW seperti terjemahan berikut: "Sebesar-besar (daripada) dosa besar adalah menyekutukan Allah, membunuh manusia, derhaka kepada ibu bapa dan menjadi saksi palsu"(Hadis riwayat Bukhari). Petikan tersebut merumuskan bahawa dakwah yang diterima oleh Anuar menerusi secara lisan yang disampaikan oleh ustaznya mencapai matlamatnya. Oleh itu, hal ini sejajar dengan teori Pengkaedahan Melayu menerusi Pendekatan Dakwah dari aspek "Dakwah Memerlukan Rasional", iaitu memperihalkan bahawa dakwah suatu penyampaian yang bersifat penilaian kritis. Setiap yang berlaku mempunyai sebab dan musababnya dalam Islam. Sementelahan, hal ini jelas memperlihatkan bahawa pendekatan dakwah yang terdapat dalam teori Pengkaedahan Melayu berlandaskan fakta dan logika. Dakwah berteraskan pemikiran kritis dan berdasarkan al-Quran dan sunnah. Segala yang diciptakan oleh Allah SWT mempunyai alasan yang kukuh secara teori dan praktikal.

Selain itu, dakwah memerlukan rasional juga dapat dilihat menerusi situasi perkahwinan Masudah dan Marzuki yang telah memberikan tamparan hebat kepada isteri pertamanya, iaitu Halijah. Halijah berang dengan tindakan suaminya yang secara senyap-senyap mengahwini wanita Inggeris itu tanpa pengetahuannya. Apabila tiba giliran Marzuki ke rumah isteri pertamanya, Masudah merelakan beliau ditinggalkan atas dasar kedudukannya sebagai isteri kedua yang terpaksa akur untuk berkongsi suami. Menerusi konteks 
ini, Marzuki mengahwini Masudah atas dasar cintanya kepada wanita Inggeris itu dan juga untuk membimbing Masudah ke jalan yang benar sebagai saudara baru. Kerasionalan cara Masudah berfikir dalam menjalani bahtera perkahwinannya membuktikan teguhnya pegangan Islam beliau dalam menghadapi detik yang sukar seperti petikan berikut:

\begin{abstract}
Suamiku belum datang. Denganku, suamiku tidak menggaris ketentuan atau giliran. Sejak mula dia hendak berkahwin denganku, dia meletak syarat begitu dan aku pula sedia menerima. Dari sedikit sebanyak hukum Islam yang pernah aku baca, semua kewajipan ini akan gugur jika aku sendiri merelainya. 'Arrida saiyidulahkam', (keredaan itu penghulu segala hukum), demikian hadis yang pernah aku baca.
\end{abstract}

(Azizi Haji Abdullah, 2009 p. 50)

Petikan tersebut menyatakan bahawa melalui pembacaan yang dibaca oleh Masudah (dakwah berbentuk tulisan) mengajarnya untuk bersifat rasional dalam membuat sebarang keputusan. Oleh itu, menerusi petikan di atas Masudah dilihat pasrah dan reda sebagai isteri kedua yang berkongsi kasih. Petikan hadis turut menyebut bahawa jika isteri-isteri yang dikahwini seorang lelaki merelakan dan reda atas sebarang syarat berkaitan dengan giliran suami ke rumah madu-madunya, maka semua kewajipan ini akan gugur secara sendirinya. Islam dalam poligami itu adil, poligami bukannya untuk menyeksa kaum wanita untuk kepentingan suami, malah poligami adalah untuk memelihara darjat dan kebesaran wanita yang dikahwininya. Oleh itu, menerusi ulasan berikut sejajar dengan teori Pengkaedahan Melayu dari aspek "Dakwah Memerlukan Rasional". Dakwah tidak mempertaruhkan fahaman yang melulu. Dakwah adalah berlandaskan fakta dan logika dan bersesuaian dengan pemikiran manusia yang bertamadun. Dakwah dalam Islam tidak sama sekali menjadikan agama sebagai tiket untuk menghalalkan perkara yang salah. Oleh hal yang demikian, dakwah yang bersifat rasional ialah dakwah yang berteraskan pemikiran kritis dan berdasarkan al-Quran dan sunnah bersifat sejagat serta diterima oleh semua manusia.

Di samping itu, dapat dilihat juga aspek dakwah memerlukan rasional menerusi watak Masudah yang menjalani kehidupan sebagai seorang Muslimah sejati dan berpegang teguh dengan ajaran Islam. Ketakwaannya sebagai seorang saudara baru dalam Islam tidak pernah disia-siakan begitu sahaja. Malah, Masudah dilihat sering meluangkan masa membuat amal 
kebajikan di rumah-rumah anak yatim dan mempelajari agama di masjidmasjid bagi memperkukuh pegangan agamanya. Hal ini dapat dilihat menerusi petikan tersebut:

"Kalau memeluk Islam, Udah akan mendapat segala kemudahan sebagai seorang baru!" Tiba-tiba Masudah menjegil padaku tapi kemudiannya disepetkan pula. Dia ketawa mengejek di atas kecangkatan fikiranku. "Sangat singkat fikiran Zuki”, katanya. "Apakah memeluk Islam itu untuk mendapatkan surat izin lalu membolehkan Udah meminta sedekah? Yang penting dalam Islam, bukan bagaimana hendak hidup, tapi cara hidup dan mahu mengisi apa dalam hidup. Dari buku-buku yang Udah baca, Islam sangat menekan cara hidup dan pengisian erti hidup itu sendiri!"

(Azizi Haji Abdullah, 2009, p. 162)

Masudah dalam petikan tersebut menunjukkan bahawa Islam yang dipelajarinya tidak meletakkan atas nama "saudara baru" untuk memperoleh segala kemudahan. Bagi Masudah, Islam sebuah agama yang suci dan unggul. Islam memberikan jaminan pertolongan serta kemenangan kepada umat manusia yang berpegang teguh dan meyakini sebenar-benarnya agama ini. Sehubungan dengan ini, keperibadian pendakwah amat penting dalam menyebarkan rasional sesuatu pembahasan dakwah. Keperibadian pendakwah yang memiliki sifat tersebut dapat menarik minat sasaran dakwahnya dalam menerima mesej yang disampaikan oleh pendakwah. Hal ini jelas membuktikan bahawa dakwah yang mencapai matlamatnya adalah apabila pendakwah berupaya membahaskan persoalan agama dengan rasional dan bernas serta mesej yang disampaikan itu sampai kepada sasaran pendakwah. Oleh itu, didapati bahawa, hal ini sejajar dengan teori Pengkaedahan Melayu menerusi Pendekatan Dakwah dari aspek "Dakwah Memerlukan Rasional", iaitu dakwah berlandaskan fakta dan bersifat kritis. Aspek ini turut memperihalkan bahawa dakwah ialah suatu penyampaian berdasarkan fitrah dan kebenaran yang rasional.

\section{Dakwah Penyatuan Masyarakat}

Dakwah bukan sahaja dapat menyelamatkan umat Islam daripada terus bergelumang dengan kemaksiatan dunia malah dakwah dapat menyatukan masyarakat Islam. 
Oleh itu, masalah yang paling ketara dalam kalangan umat Islam pada hari ini ialah sikap berpecah-belah dan mementingkan diri sendiri. Umat Islam pada hari ini tidak meletakkan hukum Islam dalam tatacara kehidupan mereka seharian. Oleh itu, menjadi tanggungjawab besar bagi pendakwah untuk menyebarluaskan kepada seluruh umat Islam agar kemaksiatan tidak bermaharajalela dan tidak menjadi darah daging yang sudah sebati dalam diri mereka. Penyatuan akidah penting bagi menyatupadukan semula umat Islam yang semakin haus dengan pegangan agama Islam. Penyatuan ini adalah berasaskan satu sumber, iaitu al-Quran. Pernyataan ini dijelaskan dalam Surah al-Imran ayat 103 yang bermaksud:

Dan berpegang teguhlah kamu sekalian kepada tali Allah (agama Islam), dan janganlah kamu bercerai-berai; dan kenanglah nikmat Allah kepada kamu ketika kamu bermusuh-musuhan (semasa jahiliah dahulu), lalu Allah menyatukan di antara hati kamu (sehingga kamu bersatu-padu dengan nikmat Islam), maka menjadilah kamu dengan nikmat Allah itu orang-orang Islam yang bersaudara. Dan kamu dahulu telah berada di tepi jurang neraka (disebabkan kekufuran kamu semasa jahiliyah), lalu Allah selamatkan kamu dari neraka itu (disebabkan nikmat Islam juga). Demikianlah Allah menjelaskan kepada kamu ayat-ayat keteranganNya, supaya kamu mendapat petunjuk hidayah-Nya.

(Mushaf Tajwid Berserta Terjemahan dalam Bahasa Malaysia, 2006, p. 63)

Ayat ini menjelaskan bahawa mukmin yang sempurna ialah mukmin yang bersatu padu dan menjalinkan persaudaraan sesama Islam serta berpegang teguh kepada ajaran Allah SWT. Umat Islam disarankan untuk bertakwa ke jalan yang diredai serta tidak bermusuhan antara sesama manusia. Islam melarang keras perpecahan dan juga perbalahan. Oleh itu, jika ada antara mereka yang berada dalam kesesatan dan kejahilan, maka menjadi tanggungjawab umat Islam yang lain untuk tampil menghulurkan bantuan serta pertolongan bagi membimbing mereka ke jalan yang benar.

Oleh hal yang sedemikian, menerusi novel Suriati terserlah paparan dakwah bersifat penyatuan masyarakat yang disuguhkan oleh pengarang. Pengarang mengemukakan aspek tersebut menerusi watak Masudah. Hal ini dapat diperhatikan menerusi pembacaan Masudah mengenai agama Islam. Masudah mendapati bahawa Islam merupakan agama sejagat yang tidak mengira bangsa, taraf kedudukan, pangkat dan harta. Kedudukan 
umat Islam adalah sama di sisi Allah SWT. Islam menurut hemat Masudah menyatukan umatnya dalam satu pegangan akidah yang sama yang mengakui kewujudan Allah SWT yang Esa dan nabi Muhammad SAW sebagai rasul yang diutus oleh-Nya:

Dua hari selepas itu, aku bergegas ke perpustakaan Perth lagi kerana di sana aku percaya ada kitab-kitab yang ditulis oleh orang-orang yang jujur dan adil, tidak seperti kitab pertama yang aku pinjam. Aku pun meminta sebuah buku tentang Muhammad, pemimpin umat Islam yang terakhir. Apabila aku meneliti watak Muhammad, aku berasa kagum dan aku terasa sedang berada di dalam Islam yang benar-benar sejagat. Tak semena-mena aku terasa begitu. Maka selepas itu, aku dihantui dan digomoli persoalan agama yang menuntut aku memihak kepada kebenaran.

(Azizi Haji Abdullah, 2009, pp. 138-39)

Petikan tersebut menyatakan bahawa Masudah mula tertarik dengan keunikan agama Islam yang dianggapnya sebuah agama yang bersifat universal dan berpegang teguh dengan satu akidah. Hal ini jelas membuktikan bahawa dakwah menerusi penulisan iaitu melalui pembacaannya dapat menyatupadukan masyarakat. Penyatuan umat Islam menerusi dakwah adalah amat penting dalam sesebuah masyarakat. Sehubungan dengan ini, dakwah bukan sahaja dapat membina sahsiah dan keperibadian mukmin malah merupakan nadi untuk menyatupadukan umat Islam. Dakwah yang dilalui oleh Masudah menerusi pembacaannya menerusi sikap terpuji junjungan nabi Muhammad SAW secara tidak langsung membentuk keperibadian dan sahsiah diri Masudah. Hakikatnya, dakwah dapat membina pembinaan akhlak manusia ke arah yang lebih baik dan membawa kebaikan kepada agama Islam itu sendiri dan seterusnya alam sejagat. Oleh itu, hal ini sejajar dengan teori Pengkaedahan Melayu dari aspek "Dakwah Adalah Bersifat Penyatuan Masyarakat". Pendekatan ini memperlihatkan bagaimana dakwah bukan sahaja dapat menyatukan umat Islam yang lain malah dapat membentuk keperibadian ke arah yang lebih baik.

Percarian Masudah terhadap agama Islam semakin jelas apabila beliau berkenalan dengan sebuah keluarga Islam secara tidak sengaja di sebuah restoran. Beliau banyak mendalami dan mempelajari ajaran agama Islam melalui keluarga Islam yang dikenalinya itu. Kemuncak penghijrahan Masudah sebagai saudara baru, telah meletakkan beliau pada satu tahap, iaitu 
Islam ialah nadi dalam kehidupannya. Dakwah yang dilalui oleh Masudah sama ada dalam bentuk tulisan, lisan dan tingkah laku memberikan hidayah buat dirinya.

"Udah melihat satu pembentukan budaya daripada ajaran Islam dan ini sesuatu yang unik," katanya. "Kelainan dalam kesatuan. Kelainan dalam budaya, ras, tapi satu dalam akidah sehingga dapat terjadi satu kesopanan dan kesusilaan". "Islamlah itu!"

(Azizi Haji Abdullah, 2009, p. 160)

Berdasarkan petikan tersebut dapat difahami bahawa dakwah dapat menyatupadukan umat Islam. Masudah mendapati agama Islam memperlihatkan sisi yang mulia, iaitu mengeratkan silaturahim dan perpaduan ukhwah sesama manusia. Penyatuan umat Islam adalah penting dalam sesebuah masyarakat. Hal ini sejajar dengan teori Pengkaedahan Melayu dari aspek "dakwah penyatuan masyarakat", iaitu memperihalkan dakwah dapat membendung pertelingkahan serta perpecahan antara umat Islam dan menyatupadukan masyarakat. Dalam cakupan yang lain pula, dakwah berupaya membentuk akhlak manusia ke arah yang lebih baik dan mengajak manusia mengabdikan diri kepada Allah SWT.

Dakwah yang dilalui oleh Masudah adalah melalui pembacaan dan pemerhatian tingkah laku yang ditunjukkan oleh masyarakat Islam dan beliau tertarik dengan agama Islam yang mempercayai konsep kewujudan Tuhan yang satu. Masyarakat Islam bagi Masudah memuliakan rumah ibadah mereka, iaitu masjid dan bersatu di bawah satu pegangan akidah yang sama:

"Bagiku, dengan banyaknya masjid di sepanjang jalan membuktikan
mereka sedang berlumba beribadah di samping kerja harian. Mereka
menegakkan masjid kerana mahu berlumba menegakkan rumah Allah
yang mereka anggap berkat. Mereka tidak perlu berhimpun pada hari
tertentu dan kemudian lupa pada hari yang lain. Setiap waktu mereka
bersalaman, bermaafan dengan menghulur tangan tanda keredaan.
Udah amat tertarik tentang ini. Islam dapat menyatukan atas nama
akidah!"

(Azizi Haji Abdullah, 2009, p. 163)

Petikan tersebut mengutarakan dakwah menerusi contoh teladan. Menerusi pemerhatian Masudah, umat Islam memuliakan rumah ibadah, 
iaitu masjid dengan melakukan solat berjemaah beramai-ramai mendekatkan diri dengan Allah SWT. Islam menurut hemat Masudah menyatupadukan umatnya di bawah satu pegangan akidah yang sama. Solat berjemaah dapat mengumpulkan manusia di rumah Allah (masjid) untuk mencari keredaanNya. Solat berjemaah ialah kunci membina kekuatan dan tamadun umat Islam. Pengarang memperlihatkan solat berjemaah yang menyatupadukan masyarakat Islam sejagat. Dakwah yang diperlihatkan menerusi petikan di atas adalah menerusi contoh teladan dan akhlak. Solat berjemaah mampu melahirkan masyarakat yang bersifat kasih sayang, bersatu hati dan bertolak ansur. Oleh itu, hal ini sejajar dengan teori Pengkaedahan Melayu dari aspek "Dakwah Adalah Penyatuan Masyarakat", iaitu memperihalkan aspek dakwah yang menyatukan umat untuk bersatu-padu, tidak mementingkan diri sendiri dan mementingkan kemaslahatan masyarakatnya.

\section{Dakwah Bukan Induksi Psikologi}

Dakwah merupakan pekerjaan seorang Muslim yang sedar akan tanggungjawab terhadap agamanya. Oleh itu, dakwah yang berkesan ialah dakwah yang mencapai matlamatnya, iaitu apabila mad'u menerima dakwah yang disampaikan dengan penuh ketakwaan dan keinsafan terhadap mesej dakwah yang disampaikan. Dakwah tidak akan mencapai kesempurnaan jika disampaikan dengan menggunakan kekerasan dan juga pendekatan dakwah itu sendiri tidak disampaikan dengan cara dakwah Islam yang penuh hikmah.

Selain itu, dakwah perlu dilakukan dengan keadaan yang sedar dan bukannya dalam keadaan yang tidak sedar atau separuh sedar. Menurut alFaruqi (1998) dakwah bukan kerja ahli sihir, ilusi, berseronok atau sejenis psikologi. Hal ini jelas menyatakan bahawa dakwah dilakukan secara serius dan bukan untuk keseronokan semata-mata. Prinsip dakwah yang menyatakan dakwah bukan induksi psikologi bermaksud mad'u berada dalam keadaan sukarela, waras dan tidak dipengaruhi oleh sesiapa melainkan untuk mendapat keredaan Allah SWT.

Menerusi novel Suriati, plot yang memperlihatkan dakwah bukan induksi psikologi terserlah pada awal garapan jalan cerita novel ini. Watak seorang anak yang bernama Anuar yang membenci bapanya dan menyifatkan bapanya seorang yang dingin dan tidak mengambil berat akan hal dirinya. Bapa Anuar merupakan seorang guru sekolah rendah dan menghabiskan masa dengan menulis. Bagi Anuar, dunia bapanya hanyalah menulis, tanpa mempedulikan apa-apa yang berlaku di sekelilingnya. Anuar dibesarkan tanpa kasih sayang seorang ibu dan beliau tidak pernah berjumpa dengan 
ibunya sejak lahir. Mujurlah pegangan agama yang diterapkan dalam diri Anuar membataskannya untuk membenci bapa kandungnya:

Marah semakin membara tapi aku masih menghormatinya. Mujurlah ajaran agama tentang besarnya dosa menderhakai ibu bapa aku terima dari ustaz sekolah, menjadi peganganku. Tapi itulah, kasih sayangku dalam keadaan 'benci' ini masih kental. Aku tidak tahu mengapa dalam benciku ada sayang. Mengapa dalam meluatku ada kasih.

(Azizi Haji Abdullah, 2009, p. 37)

Dakwah yang diperlihatkan di sini ialah dakwah yang bersifat bukan induksi psikologi. Dakwah yang disampaikan telah mencapai matlamatnya apabila Anuar menginsafi dan sedar akan hukum seorang anak membenci kedua ibu bapanya. Anuar menerima dakwah tersebut dengan penuh ketakwaan dan keinsafan serta mengikut lunas Islam.

Dakwah yang dilalui oleh Masudah pula memaparkan konsep dakwah bukan induksi psikologi. Dakwah yang berlaku terhadap Masudah berlaku secara waras dan sedar. Petikan juga memperlihatkan bahawa dakwah yang diterima oleh watak Masudah tidak berdasarkan perbuatan yang melibatkan kerja sihir yang dilakukan oleh da $i$. Pendekatan ini jelas membicarakan bahawa "Dakwah Bukan Induksi Psikologi" berdasarkan aspek pendekatan dakwah yang termaktub dalam teori Pengkaedahan Melayu.

Sementelahan, dalam konteks lain pula, Masudah yang telah memeluk Islam setelah mengahwini Marzuki, menjalani kehidupan sebagai seorang Muslimah sejati yang begitu kuat pegangan agama dan akidahnya. Masudah yang mencari-cari erti sebuah agama dilihat menemui jawapannya setelah memeluk Islam. Agama Islam bagi Masudah merupakan sebuah agama yang suci, agama yang menemukannya dengan segala jawapan yang dicarinya selama ini:

Dalam masa perkahwinan inilah aku dapati Masudah Steinmann semakin rapat dengan agama. Tidak pernah Masudah gelincir menghadiri kuliah agama di masjid. Jika ada di mana-mana majlis membaca tafsir Quran, Masudah akan berusaha hadir. Di rumah sewa Jalan P. Ramlee pula Masudah menjadi tumpuan. Dia membentuk satu perkumpulan perempuan dengan tujuan membuat amal, terutamanya membantu anak-anak yatim.

(Azizi Haji Abdullah, 2009, p. 170) 
Petikan di atas memperlihatkan keteguhan pegangan Masudah terhadap agama Islam. Pengarang menyuguhkan aspek dakwah menerusi petikan di atas. Dakwah yang diterima oleh Masudah berjaya mengubah Masudah menjadi seorang Muslimah sejati yang tidak hanya memeluk Islam untuk mengahwini lelaki Melayu. Masudah memeluk Islam adalah kerana kefahamannya yang mendalam terhadap agama ini. Oleh yang demikian, dakwah yang dilalui oleh Masudah memperlihatkan dakwah yang mencapai matlamatnya, iaitu apabila mad'u menerima dakwah yang disampaikan dengan penuh ketakwaan dan keinsafan terhadap mesej dakwah yang disampaikan. Dakwah yang berlaku dalam diri Masudah adalah secara sedar dan waras, dan disampaikan dengan cara dakwah Islam. Sejajar dengan itu, dakwah diperlihatkan sebagai bukan kerja ahli sihir, ilusi, berseronok atau sejenis psikologi. Seorang Muslim perlu sedar akan tanggungjawab terhadap agamanya. Pernyataan ini menyatakan bahawa dakwah bukanlah suatu perkara yang dilakukan secara tidak serius atau pun untuk keseronokan. Oleh itu, hal ini sejajar dengan teori Pengkaedahan Melayu dari aspek "dakwah bukan induksi psikologi", iaitu memperihalkan bahawa dakwah tidak bersifat induksi psikologi, dakwah dilakukan secara sedar dan waras.

Perjalanan Masudah sebagai seorang saudara baru dalam Islam disifatkan sebagai seorang wanita yang arif dan warak dalam menyebarkan ajaran Islam. Masudah telah melalui fasa-fasa penghijrahan sebagai seorang Muslim sejati menerusi pendekatan dakwah dalam bentuk lisan, tulisan dan contoh teladan serta akhlak. Dakwah sesungguhnya menjadi tugas dan tanggungjawab umat Islam yang perlu dilaksanakan di muka bumi ini demi untuk mencapai kesejahteraan hidup di dunia dan di akhirat:

Masudah berkata sesuatu dengan suara terteran-teran, kesungguhan untuk meyakinkan kepada penghuni tua di depannya. Segala-galanya di luar pengetahuanku. Kadang-kadang dia membaca ayat-ayat Quran dan ditafsirnya dengan lancar. Kadang-kadang dia mengeluarkan hujah daripada injil. Disebutnya petikan dari Mathew. Dinukilkan dari dalil Zabur dan Taurat. Mencurah-curah hujahnya daripada Injil. Dia menerangkan betapa penyelewengan Yahudi dan akhirnya tersedu-sedu apabila melihat nasib umat Islam yang mengabaikan perintah Quran. 
Pendekatan dakwah yang dalam karya Azizi Haji Abdullah ini memperlihatkan bahawa dakwah mampu membentuk manusia ke arah kebaikan. Dakwah yang dilalui oleh Masudah ternyata telah mengubah kehidupannya daripada seorang yang jahil mengenai agama Islam kepada seorang wanita yang warak dan arif mengenai selok-belok agama tersebut dan mendekatkan dirinya kepada Allah SWT (Rabiatul Adawiyah ${ }^{5}$ ). Petikan tersebut memperlihatkan bagaimana seorang saudara baru dalam Islam memberikan hujah mengenai kebesaran kitab suci al-Quran yang diperturunkan oleh Allah SWT kepada umat Islam bagi membimbing mereka ke jalan yang benar dan tidak tersasar daripada kesesatan yang menyesatkan. Kebenaran yang diperoleh oleh Masudah menerusi pembacaan, iaitu dakwah yang diterimanya menerusi tulisan mengenai penyelewengan yang dilakukan oleh kaum Yahudi menyedarkannya bahawa Islam merupakan agama yang benar yang diutuskan oleh Allah SWT kepada hambanya. Hal ini jelas membuktikan bahawa dakwah yang dilalui oleh Masudah memaparkan konsep dakwah bukan induksi psikologi. Pendakwahan yang berlaku terhadap Masudah adalah secara waras dan sedar. Petikan juga memperlihatkan bahawa dakwah yang diterima oleh watak Masudah tidak berdasarkan perbuatan yang melibatkan kerja sihir yang dilakukan oleh da $i$. Pendekatan ini jelas membicarakan bahawa "dakwah bukan induksi psikologi" menerusi aspek pendekatan dakwah yang termaktub dalam teori Pengkaedahan Melayu. Dakwah yang dilakukan perlu dilakukan dengan ilmu, iman dan akhlak antara kedua-duanya, iaitu da ' $i$ dan mad'u.

\section{KESIMPULAN}

Pendekatan dakwah yang terkandung dalam teori Pengkaedahan Melayu bersesuaian untuk diterapkan dalam novel Suriati garapan Azizi Haji Abdullah ini. Novel yang berkisar pergolakan masyarakat yang berunsurkan keagamaan ini mampu menjadi wadah untuk meningkatkan nilai ketakwaan dan ketaatan untuk mengabdikan diri ke jalan Allah SWT. Pendekatan dakwah memperlihatkan kesesuaiannya dalam menganalisis novel yang berunsurkan keagamaan ini kerana persoalan dan permasalahan yang diutarakan bermatlamatkan untuk memperkembang keunggulan Islam, di samping untuk mengagungkan kebesaran Allah SWT. Pendekatan Dakwah yang terdapat dalam teori Pengkaedahan Melayu janaan Hashim Awang ini menunjukkan kerelevanan menelusuri elemen dan komposisi sastera berunsur Islam. Pendekatan dakwah yang diterapkan terhadap novel yang dikaji memperlihatkan bahawa sastera berunsur Islam mampu menjadi alat 
bagi mempertingkatkan nilai ketakwaan, mengagungkan kebesaran Allah SWT dan mengembangkan keunggulan Islam berlandaskan al-Quran dan al-Hadis. Pendekatan dakwah mampu memberikan impak yang baik dalam aplikasinya terhadap novel yang berunsurkan keagamaan ini. Persoalan yang dipaparkan adalah untuk mempertingkatkan nilai ketakwaan dan ketaatan seorang insan terhadap Allah SWT selain dapat mengembangkan ajaran dan keunggulan Islam. Sejajar dengan ini, Pendekatan dakwah janaan Hashim Awang ini melibatkan sepenuhnya aspek dakwah yang membawa ke arah kebaikan bagi melahirkan Muslim yang teguh keimanan dan ketakwaanya selaras dengan kehendak ajaran Islam.

Selain itu, aspek dakwah jelas telah diperlihatkan dalam novel ini melalui empat metodologi dakwah oleh al-Faruqi seperti dakwah bukan paksaan, dakwah memerlukan rasional, dakwah penyatuan masyarakat, dan dakwah bukan induksi psikologi. Menerusi novel Suriati dapat diperhatikan aspek dakwah yang diterajui oleh watak utama yang mendominasi novel, iaitu Masudah Steinmann seorang saudara baru yang telah memeluk agama Islam. Pengarapan watak utama memperlihatkan pengarang menjelaskan peranan dakwah dalam kehidupan manusia dalam usaha menyeru umat manusia dan menghayati ajaran Islam. Dakwah antara $d a$ ' $i$ dan mad' $u$ perlu ada jalinan antara keduanya agar mesej dakwah dapat disampaikan dengan jayanya dan mencapai matlamat pelaksanaan sesuatu dakwah. Oleh itu, pemahaman uslub dakwah yang jelas dan mantap adalah perlu bagi memastikan agar objektif dakwah dapat disampaikan dengan berkesan. Sehubungan dengan ini, aspek dakwah sewajarnya dijadikan pegangan dalam diri setiap khalifah di muka bumi ini bagi menginsafi akan kebesaran Ilahi.

Sejajar dengan ini, penulisan berbentuk keagamaan perlu digiatkan lagi sebagai salah satu langkah untuk menyebarkan ajaran Islam di samping untuk mempertingkatkan nilai ketakwaan terhadap Allah Yang Esa. Medium pendekatan dakwah menerusi penulisan merupakan wadah yang memberikan impak yang besar terhadap khalayak. Masyarakat Islam pada hari ini, perlu disuakan dengan bahan bacaan yang berpasakkan ketauhidan dan keagamaan dengan menggalurkan perutusan yang bermanfaat terhadap kehidupan manusia dunia dan akhirat. Oleh itu, masyarakat Islam perlu bersama-sama bergandingan bahu menggalas amanat sebagai khalifah Allah SWT di muka bumi ini dengan menyebarkan dakwah dalam apa jua medium perantara. 


\section{NOTA}

1. Kitab Tajul Muluk yang mengandungi pelbagai ilmu dan juga panduan hidup yang membincangkan enam perkara pokok, iaitu mengenai manusia, kesihatan (perubatan) manusia, sifat dan gerak laku manusia, mimpi dan firasat, cakerawala dan perumahan.

2. Lihat Ahmad Sabri Osman, Mohd Farid Mohd Sharif, Raihaniah Zakaria, "Pemikiran Dakwah al-Faruqi: Kajian Dari Sudut Metodologi dan Isi Kandungannya". ESTEEM Academic Journal, 9(2), 96-107.

3. Da' $i$ bermaksud Muslim atau Muslimat yang menjadikan dakwah sebagai suatu tugasan.

4. Mad'u bermaksud objek dakwah Islam iaitu segenap manusia, iaitu Muslim dan bukan Muslim.

5. Merupakan seorang wali Allah yang warak dan mengabdikan sepenuhnya dirinya kepada Allah SWT.

\section{RUJUKAN}

Ab. Aziz Mohd Zin. (1997). Pengantar dakwah Islamiah. Kuala Lumpur, Malaysia: Penerbit Universiti Malaya.

Abdullah Muhammad Basmeih (Sheikh.) (2006). Mushaf tajwid berserta terjemahan ke dalam bahasa Malaysia. Kuala Lumpur: Darulfikir.

Ahmad Sabri Osman, Mohd Farid Mohd Sharif dan Raihaniah Zakaria. (2013). Pemikiran dakwah al-Faruqi: Kajian dari sudut metodologi dan isi kandungannya. ESTEEM Academic Journal, 9(2), 96-107.

al-Faruqi, I.R. (1998). Islam and other faiths. (Ataullah Siddiqui, ed.). Leicester, United Kingdom: The Islamic Foundation, \& Herndon, USA: International Institute of Islamic Thought.

Ali Mahfuz. (1975). Hidayah al-Mursyidin ila Turuq al-Wa'z wa al-Khitabah. Mesir: Dar Misr li al-Tiba'ah.

al-Aluri, Adam 'Abdullah. (1979). Tarikh al-Dakwah Baina al-Ams wa al-Yawm. Kaherah: Maktabah Wahbah.

Hashim Awang. (1994). Pengkajian sastera: Pengkaedahan Melayu. Pengarang, teks dan khalayak. Sahlan Mohd. Saman (ed.). Kuala Lumpur: Dewan Bahasa dan Pustaka.

Hashim Awang. (1999). Teori Sastera Sendiri: Pengkaedahan Melayu. Kolokium Membina Teori Sastera Sendiri. Kuala Lumpur: Dewan Bahasa dan Pustaka. Hashim Awang. (2002). Teori Pengkaedahan Melayu dan Prinsipnya. Bengkel Teori Sastera. Dewan Bahasa dan Pustaka: Kuala Lumpur.

Hashim Awang. (2003). Sejarah Kesusasteraan Melayu Moden: Esei Kritikan. Kuala Lumpur: Dewan Bahasa dan Pustaka.

Kamus Dewan. (2015). Edisi Keempat. Dewan Bahasa dan Pustaka: Kuala Lumpur. 
MALAY LITERATURE VOLUME 32 NUMBER 1 JUNE 2019

Muhammad al-Ghazali. (1981). Ma'a Allah, Dirasat fi al-Da'wah wa al-Du'at. Beirut: Dar al- Ihya' al- Turath al- 'Arabi.

Nasrudin. (2008). Dakwah Islam dalam pemikiran lsma'il Raji al-Faruqi. Komunika, 2(1), 32-41.

Shofian Ahmad. (2011). Falsafah dakwah dalam ekonomi Islam. Jurnal AlHikmah, 3(3), 45-55.

Salasiah Hanin Hamjah. (2010). Pendekatan dakwah al-Ghazali kepada golongan pemerintah. Jurnal Al-Hikmah, 2(2), 51-67

Sayyid Nawfal. (1977). al- Da'wah Ila Allah Ta'ala Khasaisuha Muqawwimatuha Manahijuha. Mesir: Jamiah al- Azhar.

Received: 23 January 2019

Accepted: 17 April 2019 